Goldschmidt 2021 Abstract

https://doi.org/10.7185/gold2021.5674

\section{Mineralogy and crystal structure studies of the manganese oxide in Xiangtan manganese deposit, South China and its preliminary application on absorption and catalysis of formaldehyde}

\author{
LIQUN ZHAO ${ }^{1,2}$, SIDA NIU $^{1,2}$, LEI LI $^{3}$, XIANGLONG \\ $\mathrm{NIU}^{1,2}$, HUAYING WU ${ }^{1,2}$, LINGCHAO MO ${ }^{1,2}$, TONG \\ CHEN $^{1,2}$ AND MIN ZHANG ${ }^{1,2}$ \\ ${ }^{1}$ Institute of Mineral Resources Research, China Metallurgical \\ Geology Bureau \\ ${ }^{2}$ Mineral Comprehensive Utilization Research and Development \\ Center, China Metallurgical Geology Bureau \\ ${ }^{3}$ BGRIMM Technology Group \\ Presenting Author: 149211145@qq.com
}

Because of the nano-scale tunnel constructed by the active $\mathrm{Mn}-\mathrm{O}$ octahedron in cryptomelane crystals, Cryptomelane-type manganese oxides have the function of high activity in the oxidation of several VOCs. The natural cryptomelane carpeted much of the region in the form of a supergene oxide manganese ore in South China. Therein the Xiangtan manganese deposit in the southeastern Yangtze Platform occurs in black shale series in the lower part of the Datangpo Formation of Nanhua System, and cryptomelane is one of the major ore minerals here. In order to study the environmental purification capacity for the formaldehyde which is the major indoor pollutant among VOCs functioning by naturally outcropping cryptomelane, representative cryptomelane mixture samples from the Xiangtan Mn deposit in South China were analyzed in this study. Detailed analyses have been carried out using XRPD, TIMA and HRTEM. Crystal structure and particle morphology of the cryptomelane in the natural mixture, associated minerals and their content were explored. Analyses show that the major minerals presenting the Xiangtan manganese deposit supergene oxide manganese ore are cryptomelane, romanechite and hausmannite along with minor amounts of quartz and limonite. After manual gravity separation, the content of natural cryptomelane can be increased from $19 \%$ to $56 \%$. The natural cryptomelane is monoclinic crystal system and its cell parameters were given as $\mathrm{a}_{0}=9.93( \pm 0.06) \AA, \mathrm{b}_{0}=2.87( \pm 0.02)$ $\AA, \mathrm{c}_{0}=9.70( \pm 0.06) \AA$ and $\beta=90.3643^{\circ}$.

More importantly, the maximum efficiency of the natural cryptomelane catalyst for static environment with high concentration of formaldehyde oxidation was as high as $80.74 \%$ under room-temperature, and the maximum release of carbon dioxide is $202 \mathrm{ppm}$. The sample can be reused after ventilation and standing, and it still has considerable formaldehyde purification ability, suggesting the high stability of the natural cryptomelane. This study developed a natural mineral as an inexpensive and efficient catalyst for the purification of $\mathrm{HCHO}$ in industrial or indoor air environment.

Acknowledgement: this study is sponsored by the science popularization research on ferrous metal minerals in China
(DD20190379-86) and the environmental mineralogy and preliminary application study on manganese oxides from lowgrade manganese ores in Hunan and Guangxi. 